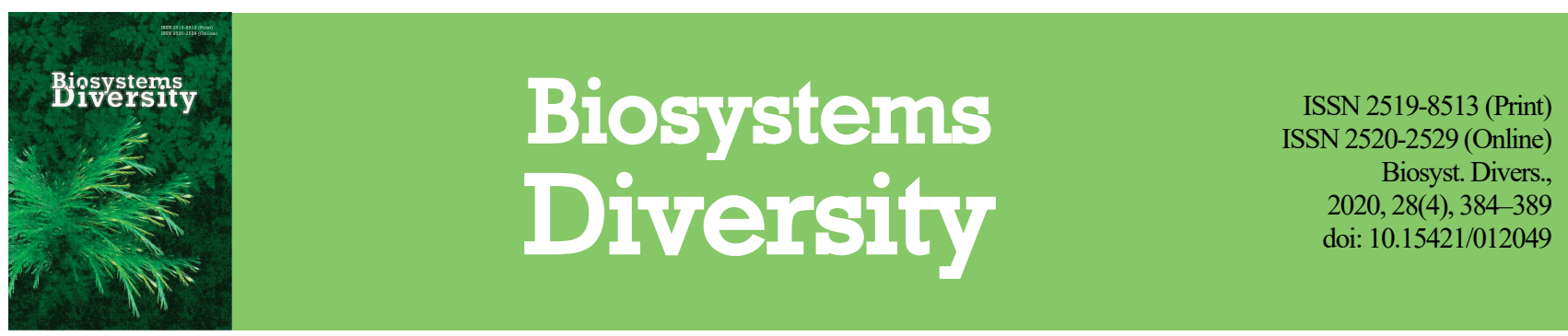

\title{
Influence of saprophages (Isopoda, Diplopoda) on leaf litter decomposition under different levels of humidification and chemical loading
}

\author{
A. P. Pokhylenko*, O. O. Didur*, Y. L. Kulbachko*, L. P. Bandura**, S. A. Chernykh** \\ *Oles Honchar Dnipro National University, Dnipro, Ukraine \\ **Dnipro State Agrarian and Economic University, Dnipro, Ukraine
}

Article info
Received 10.11 .2020
Received in revised form
05.12 .2020
Accepted 07.12 .2020

Oles Honchar Dnipro National University, Gagarin ave., 72, Dnipro, 49010, Ukraine. Tel.:+38-096-389-78-75. E-mail:vivtash@ukr.net

Dnipro State Agrarian and Economic University Serhii Yefremova st, 25 , Dnipro, 49600, Ukraine. Tel.:+38-067-919-15-93. E-mail:

bandural.p.@dsau.dp.ua

Pokhylenko, A. P., Didur, O. O., Kulbachko, Y. L., Bandura, L. P., \& Chernykh, S. A. (2020). Influence of saprophages (Isopoda, Diplopoda) on leaf litter decomposition under different humidification and chemical loading. Biosystems Diversity, $28(4), 384-389$. doi:10.15421/012049

The paper presents a study about the influence of two saprophage groups (Isopoda, Diplopoda) on leaf litter decomposition under different levels of humidification and chemical stress. Because of their worldwide distribution, we focused on the common pillbug Armadillidium vulgare (Latreille, 1804) (Isopoda, Armadillidiidae), and the common millipede species Rossiulus kessleri (Lohmander, 1927) (Julida, Julidae). The function of environment creation by the given saprophages, as destructors of dead plant matter, supporting such ecosystem services as soil fertility improvement and nutrients' turnover, is highlighted. To conduct the experiment, the animals were collected manually and using pitfall trapping. In order to bring the experimental conditions closer to the natural, the individuals were not sexed. The maximum consumption of leaf litter by woodlice was recorded in the conditions with adequate moisture $(0.5 \mathrm{~mL}$ of distilled water per box) and amounted to $2.52 \mathrm{mg} / 10$ individuals per day, which exceeds its consumption with low and increased moisture, respectively, by 1.82 and 1.24 times. As for the effect of interaction, the consumption of maple litter with optimal moisture ( $4.77 \mathrm{mg} / 10$ individuals per day) was the greatest. The largest absolute difference between broad-leaved tree species in the average weight of leaf litter consumed by woodlice was between maple leaf litter and oak leaf litter, the minimum - between robinia leaf litter and oak leaf litter. According to the results of the obtained data (Diplopoda), it can be stated that there is a statistically significant effect of chemical stress and discrepancy of the average zinc content in the object of study (in Diplopoda and their faecal pellets). We found that the diet provided did not affect the distribution of zinc in Diplopoda under conditions of chemical stress. According to the results of pairwise comparisons, we determined that the zinc content in the Diplopoda clearly differs for control and almost every concentration of zinc sulfate solution -0.03 and $0.15 \mathrm{~g} / \mathrm{L}$, the samples of which do not form a homogeneous group. The species composition, abundance and distribution in space of soil invertebrates are informative indicators which reflect the ecological state of soils, intensity in development of soil horizons as well as intensity of processes occurring in them.

Keywords: ecosystem services; millipedes; litter transformation; climate changes; chemical stress; common pill bug.

\section{Introduction}

Anthropogenic influence disturbs the ability of nature acquired in the process of evolution to self-regulate. Environmental stress alters natural landscapes and natural habitats radically, transforming the natural environment into "technogenic territories". Due to artificial changes in the natural environment, fundamental changes in the ecosystem combine, leading to progressive destruction of the biosphere, such as soil degradation, decrease in biodiversity, and desertification (Klymenko et al., 2017; Didur et al., 2018; Pokhylenko et al., 2018). Responses to human disturbance are not always traceable, but a trend towards community homogenisation is often found under strong global urbanization processes (Sfenthourakis \& Hornung, 2018).

Adapting to these changes, the animal population of ecosystems is changing. These processes are typical for regions with significant anthropogenic pressure, including such a highly industrialized region of Ukraine as Steppe Prydniprovie (Alexeyeva et al., 2016; Shulman et al., 2017). One of the natural mechanisms of the initiation of restoration of disturbed soils is the activity of saprophages in the transformation of the organic matter, for example such ecosystem engineers as representatives of Isopoda (Didur et al., 2017; Spaldonova \& Frouz, 2019; Yang et al., 2020) and Diplopoda (Jones et al., 1997; Pakhomov et al., 2009; Brygadyrenko \& Ivanyshyn, 2015; Pokhylenko et al., 2018). These saprophages have a positive effect on maintaining and improving the properties of natural soils. Terrestrial isopods (about 3700 known species in the world) inhabit temperate and tropical regions from floodplain forests to deserts (Schmalfuss,
2003). They are also known to contribute to soil biodiversity. Environmental factors and biodiversity and its functions, soil tillage, pesticide application, and chemical pollution, along with soil acidification and desertification adversely affect isopod abundance and diversity. Woodlice produce faecal pellets which decompose rapidly, and, in large amounts provide a significant source of soil fertility, allowing essential nutrients for plants to return (Striganova, 1980; Paoletti \& Hassal, 1999; Quadros \& Araujo, 2008; Leclercq-Dransart et al., 2019). This natural mechanism positively influences the sustenance and improvement of properties of natural soils. In forests, the plant and soil animal biota bind with the forest litter. The rate at which litter is decomposed is to a large extent influenced by its chemical composition, by the activity and composition of soil organisms, and by the physical microenvironment (Meentemeyer, 1978; Vasconcelos et al., 2005). Terrestrial isopods utilize more than $10 \%$ of the annual litter, causing a four-fold increase in the surface available to microorganisms.

One of the important tasks related to research on the trophic activity of saprophages is the study of their trophic priorities which determine their ecological role in functioning of the ecosystems (Roy et al., 2009; Semenyuk et al., 2011; Svyrydchenko \& Brygadyrenko, 2014). Through retention of soil functions (soil biodiversity), protection of environmental quality is supported (Solomou et al., 2019). To describe the influence of different moisture conditions on this soil mesofauna group and evaluate their seasonal dynamics regarding temperature and soil humidity fluctuations, research was conducted at three sites along a small-scale moisture gradient. Thus, ordination analysis (Oribatida case) confirmed the influences of temperature, vegetation cover, soil $\mathrm{pH}$, soil humidity and heavy metals 
(As, $\mathrm{Cu}, \mathrm{Pb}, \mathrm{Ni}, \mathrm{Mn}$ and $\mathrm{Zn}$ ) on the composition of the saprophage community (Manu et al., 2019; Jaksova et al., 2020). The heterogeneity of species richness at the area scale was correlated with a metric related to the heterogeneity of microsites with more favourable conditions, compared to the surrounding area at the same scale presence in it. In the context of global warming, an increase in soil drought is notable and litter breakdown activity could be affected. One study (Leclercq-Dransart et al., 2019) revealed that with global warming, woodlice, which are recognized as shredders of litter and bioindicators of global warming, spend less time foraging and more time seeking refuge to reduce the risk of mortality from desiccation stress. Armadillidium vulgare (Latreille, 1804) is the most affected species followed by Oniscus asellus Linnaeus, 1758. Thus, modification of the feeding behaviour of terrestrial isopods could help to slow down litter degradation and organic matter recycling.

Diplopoda is the most numerous class among millipedes (more than 8000 species). Most of them live in tropical regions of the Earth, inhabiting the upper humus-rich soil layers. These millipedes comprise a mesophilic group of invertebrates. The vast majority of them are phytosaprophages which play a significant role in the processes of primary decomposition and mineralization of plant residues. Their activity is one of the essential factors that determines the rate of circulation of substances and release of plant nutrients in the soil. As a result of their vital activity, not only do mixing and grinding of the litter and its enrichment by excrement of Diplopoda take place, but also loosening the bottom layers of soil, creating the most favourable conditions for the micropopulation of forest soils (Striganova, 1980; Brygadyrenko, 2015). Therefore, both woodlice and millipedes are considered as a prominent component of the soil arthropod litter-transformation community in many temperate habitats (Striganova, 1980; Brygadyrenko, 2015; Sfenthourakis \& Hornung, 2018; Pey et al., 2019). The objects of investigation were specimens of common pillbug Armadillidium vulgare (Latreille, 1804) (Malacostraca, Isopoda, Armadillidiidae), and the common millipede species Rossiulus kessleri (Lohmander, 1927) (Diplopoda, Julida, Julidae), which we selected because of their worldwide distribution.

Common pillbug is a member of the most xerophillous genus, widespread and common in forests and forest belts in the temperate habitats.

$R$. kessleri is a widely distributed Julida species in mid-latitude forests. It is ecologically flexible and heliophile. Based on the overview of toxicity data and test methods, some authors (Bibic et al., 1997; van Gestel et al., 2018) suggest that chemicals are more toxic to isopods when exposed through soil compared to food. In addition, the authors gave recommendations for the use of isopods in standardized laboratory toxicity tests as well as in situ monitoring studies. Besides, it has been proposed that (Bibic et al., 1997; Horvath et al., 2019) pillbugs can be used as promising models for personality research due to their responsiveness to changes in environment or labile state variables and due to the relative ease of getting repeated behavioural measurements. The chosen animals take an active part in the destruction of fallen plant material and promote increases in soil fertility. The objective of the study was the trophic activity of saprophages when modelling various environmental conditions (feeding base, moisture, chemical stress).

\section{Materials and methods}

The study sites are located in the Dnieper Lowland within the steppe zone (left bank of north steppe province). Both $A$. vulgare and R. kessleri were collected from a natural forest ecosystem in Dnipropetrovsk oblast during April and May 2019. The animals were collected manually and using pitfall trapping. The individuals were not sexed in order to bring the experimental conditions closer to the natural.

We conducted laboratory research on the trophic activity of $\mathrm{A}$. vulgare depending on trophic base and moistening (Table 1), and on the zinc accumulation pattern of $R$. kessleri specimens depending on food resources and chemical stress (Table 2). The repetition of each treatment in the experiment was fivefold. The duration of each experiment was 21 days. Samples for analysis were taken on the 3rd, 8th, 13th, 18th, and 21st days. The obtained values of the indicators were averaged.

\section{Table 1}

Experiment plan for determining consumption of leaf litter from dicotyledonous plants by Armadillidium vulgare (Latreille, 1804) depending on moistening

\begin{tabular}{lccc}
\hline \multirow{2}{*}{ Leaf litter } & \multicolumn{3}{c}{ Moisture } \\
\cline { 2 - 4 } & poor watering & adequate moisture & overwatering \\
\hline from Quercus robur & $\mathrm{x}_{1} \mathrm{x}_{5}$ & $\mathrm{x}_{16} \mathrm{x}_{20}$ & $\mathrm{x}_{31} \mathrm{x}_{35}$ \\
from Acer campestre & $\mathrm{x}_{6} \mathrm{x}_{10}$ & $\mathrm{x}_{21}-\mathrm{x}_{25}$ & $\mathrm{x}_{36} \mathrm{x}_{40}$ \\
from Robinia pseudoacacia & $\mathrm{x}_{11} \mathrm{x}_{15}$ & $\mathrm{x}_{26} \mathrm{X}_{30}$ & $\mathrm{x}_{41} \mathrm{x}_{45}$ \\
\hline
\end{tabular}

Note: $\mathrm{x}_{\mathrm{n}}$ - the mass of consumption leaf litter.

\section{Table 2}

Experiment plan for determination of zinc content in representatives of Rossiulus kessleri (Lohmander, 1927) depending on chemical stress and food resourses at adequate moisture

\begin{tabular}{|c|c|c|}
\hline \multirow[b]{2}{*}{$\begin{array}{l}\text { Chemical stress, } \\
\mathrm{g} \mathrm{ZnSO}_{4} / \mathrm{L} \text { in solution }\end{array}$} & \multicolumn{2}{|c|}{ Feeding base } \\
\hline & $\begin{array}{l}\text { leaf litter from } \\
\text { Acer campestre }\end{array}$ & $\begin{array}{c}\text { leaf litter from } \\
\text { Robinia pseudoacacia }\end{array}$ \\
\hline Control & $\mathrm{X}_{1} \mathrm{X}_{5}$ & $\mathrm{X}_{21} \mathrm{X}_{25}$ \\
\hline 0.006 & $\mathrm{x}_{6} \mathrm{x}_{10}$ & $\mathrm{X}_{26} \mathrm{X}_{30}$ \\
\hline 0.03 & $\mathrm{X}_{11} \mathrm{X}_{15}$ & $\mathrm{X}_{31} \mathrm{X}_{35}$ \\
\hline 0.15 & $\mathrm{X}_{16} \mathrm{X}_{20}$ & $\mathrm{X}_{36} \mathrm{X}_{40}$ \\
\hline
\end{tabular}

Note: adequate moisture was provided every third day with $0.25 \mathrm{~mL}$ of distilled water per box, which contained $3 \mathrm{~g}$ of dried leaf litter; $\mathrm{x}_{\mathrm{n}}-\mathrm{zinc}$ content in test objects.

Adult woodlice and diplopods were kept in $18 * 10 * 10 \mathrm{~cm}$ clear plastic boxes perforated for aeration at one end.

Leaf litter of dicotyledonous plants is considered as high quality food both for woodlice and for Diplopoda. In every box, we placed $3.0 \mathrm{~g}$ of leaf litter. Three different diets: Robinia pseudoacacia L., Acer campestre L., Quercus robur L. were used. Leaves were dried, shredded and evenly spaced. The following moisture gradation was used: poor watering ( $0.1 \mathrm{~mL}$ of distilled water per box), adequate moisture $(0.25 \mathrm{~mL}$ of distilled water per box), and overwatering ( $0.5 \mathrm{~mL}$ of distilled water per box). Once in three days, the containers were sprayed with distilled water from an atomizer to compensate moisture evaporation. For this reason, a temperature and humidity sensor Xiaomi Mijia Bluetooth Hygrothermograph LYWSDCGQ/01ZM was used. In the laboratory, the boxes were kept in a shaded place.

The number of $A$. vulgare was 20 specimens per box. The results of litter consumption were expressed in terms of 10 individuals. The average weight of live woodlice in the experiment was $18.6 \pm 0.87 \mathrm{mg}$. The number of $R$. kessleri was 10 specimens per box. The average weight of one specimen of $R$. kessleri in the experiment was $20.98 \pm 0.43 \mathrm{mg}$. In the natural conditions of the Samarskyi Forest (Novomoskovskyi, Pavlogradskyi districts within Dnipropetrovsk oblast), the possible density of Armadillidiidae family is 62 individuals $/ \mathrm{m}^{2}$, while the possible density of representatives of the Julidae family may reach 112 individuals $/ \mathrm{m}^{2}$. Population density was maintained by replacing any dead individual with another one.

Statistical analysis of the data was conducted using the statistical set: mean \pm standard error $(\mathrm{x} \pm \mathrm{SE})$. To compare the mean values of the mass consumed, the Honestly Significant Difference test or Tukey's HSD test was used. Analyzed parameters such as humidity level and the amount of zinc deposits as well were processed using variance method (MANOVA) factorial experiment, and the differences between the mean values were tested with Tukey's HSD. The average difference is considered statistically significant at $\mathrm{P}<0.05$.

\section{Results}

Isopoda. We evaluated the level of realization by $A$. vulgare of its main ecological function, participation in leaf litter transformation and decomposition under various moisture conditions.

Of the provided food supply (leaf litter from Robinia pseudoacacia L., Acer campestre L., and Quercus robur L.), woodlice consumed litter from maple leaves most actively ( $3.70 \mathrm{mg} / 10$ individuals per day), exceeding the consumption of litter from Robinia pseudoacacia L. and Quercus robur L. leaves respectively by 2.33 and 5.78 times (Table 3). 
The maximum consumption of leaf litter was recorded with adequate moisture ( $0.5 \mathrm{~mL}$ of distilled water per box), accounting for $2.52 \mathrm{mg} / 10$ individuals per day, which exceeds its consumption with low and increased moisture respectively by 1.82 and 1.24 times (Table 1 ). As for the

\section{Table 3}

Comparative characteristics of leaf litter consumption by Armadillidium vulgare (Latreille, 1804)

depending on the feeding base and moisture in the experiment $(\mathrm{mg} / 10$ individuals per one day)

\begin{tabular}{|c|c|c|c|c|}
\hline Factor & Factor level & $\mathrm{X} \pm \mathrm{SE}$ & Min & Max \\
\hline \multirow[t]{3}{*}{ Leaf litter } & Robinia pseudoacacia & $1.593 \pm 0.056^{\mathrm{a}}$ & 1.481 & 1.706 \\
\hline & Acer campestre & $3.702 \pm 0.056^{\mathrm{b}}$ & 3.590 & 3.815 \\
\hline & Quercus robur & $0.643 \pm 0.056^{\mathrm{c}}$ & 0.531 & 0.756 \\
\hline \multirow[t]{3}{*}{ Moisture } & poor watering & $1.382 \pm 0.056^{\mathrm{a}}$ & 1.270 & 1.495 \\
\hline & adequate moisture & $2.520 \pm 0.056^{\mathrm{b}}$ & 2.408 & 2.632 \\
\hline & overwatering & $2.037 \pm 0.056^{\mathrm{c}}$ & 1.924 & 2.149 \\
\hline \multirow[t]{9}{*}{ Interaction factors } & Robinia pseudoacacia + poor watering & $1.25 \pm 0.097$ & 1.055 & 1.445 \\
\hline & Robinia pseudoacacia + adequate moisture & $1.92 \pm 0.097$ & 1.725 & 2.115 \\
\hline & Robinia pseudoacacia + overwatering & $1.61 \pm 0.097$ & 1.415 & 1.805 \\
\hline & Acer campestre + poor watering & $2.49 \pm 0.097$ & 2.292 & 2.681 \\
\hline & Acer campestre + adequate moisture & $4.77 \pm 0.097$ & 4.575 & 4.965 \\
\hline & Acer campestre + overwatering & $3.85 \pm 0.097$ & 3.655 & 4.045 \\
\hline & Quercus robur + poor watering & $0.41 \pm 0.097$ & 0.215 & 0.605 \\
\hline & Quercus robur + adequate moisture & $0.87 \pm 0.097$ & 0.675 & 1.065 \\
\hline & Quercus robur + overwatering & $0.65 \pm 0.097$ & 0.455 & 0.845 \\
\hline
\end{tabular}

Note: the same letters in the column indicate statistically insignificant differences in the means of the compared pair according to the Tukey criterion.

Based on the results of the Tukey test, we determined that there was a statistically significant difference in average consumption of different food resources by woodlice (Table 3 ). The largest absolute difference in the average weight of leaf litter eaten by woodlice of broad-leaved tree species ( $3.06 \mathrm{mg} / 10$ individuals per one day, $\mathrm{P}<0.05$ ) was found to be between maple leaf litter $(3.702 \pm 0.056 \mathrm{mg} / 10$ individuals per one day) and oak leaf litter $(0.643 \pm 0.056 \mathrm{mg} / 10$ individuals per one day $)$, the minimum difference $(0.95 \mathrm{mg} / 10$ individuals per one day, $\mathrm{P}<0.05)$ was between robinia leaf litter $(1.593 \pm 0.056 \mathrm{mg} / 10$ individuals per one day $)$ and oak leaf litter $(0.643 \pm 0.056 \mathrm{mg} / 10$ individuals per one day $)$.

When conducting paired comparisons according to the Tukey method, it was found that the average consumptions of different leaf litter by woodlice, depending on the conditions of environmental moistening, statistically differ from each other. As in the case of the feeding base, their samples statistically differ from each other. The largest absolute difference in the average weight of leaf litter eaten by woodlice of broad-leaved tree species $(1.14 \mathrm{mg} / 10$ individuals per one day, $\mathrm{P}<0.05)$ was found to be between the variants with poor watering $(1.382 \pm 0.056 \mathrm{mg} / 10$ individuals per one day $)$ and those with adequate moisture $(2.520 \pm 0.056 \mathrm{mg} / 10$ individuals per one day), while the minimum difference $(0.48 \mathrm{mg} / 10$ individuals per one day, $\mathrm{P}<0.05)$ was found to be between the variants with adequate moisture $(2.520 \pm 0.056 \mathrm{mg} / 10$ individuals per one day $)$ and those with overwatering $(2.037 \mathrm{mg} / 10$ individuals per one day) (Table 3$)$.

Based on the results of the analysis of the obtained data, it is possible to confirm that the type and consumption of litter by woodlice are important and statistically significant (Table 4). In addition, the effect of interaction between the type of litter and the degree of its moistening was found to be significant. This is due to the fact that the consumption of leaf litter by woodlice occurs in an environment with a sufficient degree of moisture and does not occur in absolutely dry conditions.

\section{Table 4}

MANOVA test of litter consumption by Armadillidium vulgare (Latreille, 1804) in the experiment with different feeding base and moisture

\begin{tabular}{lccc}
\hline & Source & F-Ratio & $\mathrm{P}$ \\
\hline & Main effects & & \\
Feeding base & & 785.88 & $<0.001$ \\
Moisture & Interactions & 104.55 & $<0.001$ \\
& & \\
Feeding base + Moisture & 27.09 & $<0.001$ \\
\hline
\end{tabular}

Diplopoda. We evaluated the realization of the main ecological function of Diplopoda (R. kessleri) - destruction of leaf litter - under environmental (chemical) stress. The control recorded the lowest average content of zinc, which is logical, since in these experiments there was no chemical effect of interaction between the moisture and the food substrate species factor, the consumption of maple litter with optimal moisture $(4.77 \mathrm{mg} / 10$ individuals per day) was the greatest. The other interaction variants were less effective (Table 3 ). load, the maximum content was detected when the animals were exposed to the highest concentration (Table 5).

\section{Table 5}

Comparative characteristics of zinc content $(\mathrm{mg} / \mathrm{kg})$ in Rossiulus kessleri (Lohmander, 1927) (body) and their faecal pellets for each experimental factor and its gradation

\begin{tabular}{lllrc}
\hline \multicolumn{1}{c}{ Factor } & \multicolumn{1}{c}{ Factor level } & \multicolumn{1}{c}{$\mathrm{x} \pm \mathrm{SE}$} & Min & Max \\
\hline Chemical & Control & $174.4 \pm 34.5^{\mathrm{a}}$ & 97.6 & 251.1 \\
stress, & 0.006 & $259.9 \pm 34.5^{\mathrm{ab}}$ & 183.1 & 336.7 \\
$\mathrm{~g} \mathrm{ZnSO}_{4} \mathrm{~L}$ & 0.03 & $398.1 \pm 34.5^{\mathrm{abc}}$ & 321.3 & 474.8 \\
in solution & 0.15 & $512.1 \pm 34.5^{\mathrm{c}}$ & 435.4 & 588.9 \\
\hline Feeding & Leaf litter from A. campestre & $309.2 \pm 24.4^{\mathrm{a}}$ & 254.9 & 363.5 \\
base & Leaflitter from R. pseudoacacia & $363.1 \pm 24.4^{\mathrm{a}}$ & 308.8 & 417.3 \\
\hline Object of & R. kessleri (body) & $403.2 \pm 24.4^{\mathrm{a}}$ & 348.9 & 457.4 \\
investigation & Pellets from R. kessleri & $269.1 \pm 24.4^{\mathrm{b}}$ & 214.8 & 323.4 \\
\hline
\end{tabular}

Note: the same letters in the column indicate statistically insignificant differences in the means of the compared pair according to the Tukey criterion.

According to the results of pairwise comparisons, it was found that the zinc content in the bodies of $R$. kessleri was clearly different in the $(\mathrm{P}<0.05)$ control and almost every concentration of zinc sulfate solution -0.03 and $0.15 \mathrm{~g} / \mathrm{L}$, the samples of which did not form a homogeneous group (Table 5). The largest absolute difference in zinc content in $R$. kessleri and their faecal pellets was found to be between the control $(174.4 \pm 34.5 \mathrm{mg} / \mathrm{kg})$ and the $0.15 \mathrm{~g} / \mathrm{L}(512.1 \pm 34.5 \mathrm{mg} / \mathrm{kg})$ solution of zinc sulfate, while the minimum was found to be between the control $(174.4 \pm 34.5 \mathrm{mg} / \mathrm{kg})$ and the $0.006 \mathrm{~g} / \mathrm{L}(259.9 \pm 34.5 \mathrm{mg} / \mathrm{kg})$ solution of zinc sulfate. According to the results of pairwise comparisons, it was found that the average zinc content in $R$. kessleri representatives did not differ in relation to the type of litter these saprophages consumed - Acer campestre L. or Robinia pseudoacacia L. Samples for two feeding bases form a statistically homogeneous group. It was proved that the average zinc content in the millepedes was higher than the zinc content in their pellets. These samples form a statistically heterogeneous group of data $(\mathrm{P}<0.05$, Table 5$)$.

The results of pairwise comparison of the studied Diplopoda's food base do not confirm the presence of statistical difference in the zinc content in the animals depending on the leaf litter type. However, the results of pairwise comparison of zinc content in millipedes and their faecal pellets indicate the presence of a statistical difference (Table 5). The conditions of modelling the chemical load on Diplopoda representatives R. kessleri established that zinc content in millipedes' faecal pellets was 1.5 -fold lower than in the animals' bodies. The species of plant provided did not statistically affect the zinc accumulation. Conversely, the level of chemical load (in the line of concentrations of $\mathrm{ZnSO}_{4}-0.006,0.030$, 
$0.150 \mathrm{~g} / \mathrm{L}$ in solution) has a statistically significant effect on the zinc content in the representatives of $R$. kessleri and its excrement.

According to the results of the obtained data, it can be stated that there is a statistically significant effect of chemical stress and discrepancy of the average zinc content in the study object (in $R$. kessleri and their faecal pellets). It was found that the food base provided did not affect the distribution of zinc in R. kessleri in the conditions of chemical stress (Table 6).

\section{Table 6}

MANOVA test of zinc distribution in Rossiulus kessleri

(Lohmander, 1927) specimen and their pellets in the experiment with different food base and chemical stress

\begin{tabular}{lrc}
\hline \multicolumn{1}{c}{ Source } & F-Ratio & P \\
\hline Chemical stress & 18.76 & 0.0002 \\
Food base & 2.45 & 0.1489 \\
Object of investigation & 15.14 & 0.0030 \\
\hline
\end{tabular}

\section{Discussion}

The complex interactions between stand characteristics and forest site variables result in specific understorey microclimate conditions, which are essential for many forest-dwelling organism groups. The authors (Kovacs, et al., 2017) suggest that structural elements have a stronger influence on microclimate conditions than tree species composition of the overstorey. Thus, it was concluded that the structure of the saprophage community (Oribatid case) was influenced by temperature and humidity (Nae \& Bancila, 2017).

The decomposition rate of black locust (Robinia pseudoacacia L.) leaves was higher than that of oak leaves, most likely because of the higher $\mathrm{N}$ content in black locust leaves (Tateno et al., 2007). In the extract of $R o$ binia pseudoacacia L. leaves the highest content of polyphenols and crude protein was found (Zhang et al., 2012; Marinas et al., 2014). Hassall \& Dangerfield (1990) concluded that $A$. vulgare populations (Breckland district of East Anglia) are more likely to be regulated from "below" by competing for limited food (intra-specific competition) than from "above" by natural enemies. Besides the competition for high quality food reduces juvenile growth and directly affects the population density (Rushton \& Hassal, 1987). The researchers noticed that the isopods are unevenly distributed (Brigic et al., 2019), and their distribution depends on the litter mass and loss due to forest fires : such areas are repopulated by woodlice reluctantly (Gongalsky et al., 2005). The increase in the abundance of Isopoda ( $+323 \%)$ and some other soil dweller groups is caused by irrigation (Johnson et al., 2018).

The data obtained by van Straalen et al. (2001) illustrate the extremely complicated relationship between metal residues in invertebrates and metal concentrations in soil. The authors concluded that for most of the saprophageous and predatory arthropods studied, neither total concentrations nor exchangeable concentrations in soil are good predictors; species-specific feeding mechanisms and metal physiologies seem to be the main determinants. Ghemari et al. (2019) determined the competition of cadmium $(\mathrm{Cd})$, lead $(\mathrm{Pb})$, zinc $(\mathrm{Zn})$ and copper $(\mathrm{Cu})$ on their assimilation on the food consumption and the growth of the terrestrial isopod Porcellio laevis Latreille, 1804. The effects of urbanization on trace element concentrations $(\mathrm{Ba}, \mathrm{Cu}, \mathrm{Fe}, \mathrm{Mn}, \mathrm{Pb}$, and $\mathrm{Zn})$ and fluctuating asymmetry of $A$. vulgare individuals in and around Debrecen city, Hungary were evaluated by Papp et al. (2019). The researchers found that urbanization had a notable effect on $\mathrm{Cu}$ and $\mathrm{Ba}$ accumulations by $A$. vulgare from soil and leaf litter. At the same time, the anthropogenic activities did not affect the symmetry of the tested traits of $A$. vulgare individuals. When simulating various environmental conditions (moisture, food supply), it was determined that one of the most important factors that not only regulate the intensity of feeding (Moulton et al., 2019), but also have a significant effect on the activity of digestive enzymes (Bendiksen et al., 2003; Salvado et al., 2006), is temperature. In addition to this factor, the humidity of the environment is important in the case of soil saprophages (Striganova, 1980; Brygadyrenko, 2014).

It is important to take into account that over the recent decades, against the background of natural temperature fluctuations in the study region, there has been an increase in aridization of the steppe climate - an increase in average monthly summer temperatures, an increase in the number of dry days (Gritsan, 2000), provoking chronic stress in representtatives of soil saprophages. When modeling various environmental conditions (moisture, food supply) with involvement of ecosystem engineers as woodlice inhabiting forest ecosystems in the study region, it was determined that the consumption of leaf litter depends both on the moisture of the habitat and on the specifics of the food supply. The impact of these factors on litter consumption by woodlice is statistically significant depending on the nature of moisture (poor watering, adequate moistening, overwatering) and leaf litter type (litter from Robinia pseudoacacia L., Acer campestre L., and Quercus robur L. leaves, Table 1). The surveys revealed that active consumption of leaf litter by woodlice is achieved in the presence of leaf litter from maple and adequate moistening $(4.77 \mathrm{mg}$ litter/10 individuals per day). Leaf litter from Qurcus robur $\mathrm{L}$. was consumed least actively by woodlice ( $0.643 \mathrm{mg} \mathrm{litter} / 10$ individuals per day), and poor consumption was observed with poor watering (1.382 $\mathrm{mg}$ litter/10 individuals per day, Table 1).

The greatest environmental hazards in the study region (as well as throughout the world) are heavy metals (Koval et al., 2012; Semenov et al., 2019). Research has revealed that even essential metals such as copper, nickel, zinc and others, when they accumulate in the soil, pose a potential threat to the life of living systems. It is known that they are capable of disrupting the integrity of physiological and biochemical processes and causing serious changes in metabolic reactions in invertebrates (Basha \& Rani, 2003; Atli \& Canli, 2007). It should be noted that heavy metals enter the body of some animals predominantly with food (Kamunde et al., 2002; Henny et al., 2003). In addition, heavy metals are able to reduce the activity of proteinases in the digestive tract both in vivo and in vitro (Golovanova et al., 1999; Gutow et al., 2006). Our study shows that millipedes accumulate zinc in direct proportion to the level of chemical stress in the environment. Moreover, statistically significantly more zinc is accumulated directly in animals (1.5 times) than is contained in their faecal pellets (Table 5). This accumulation does not depend on the type of food supply provided (leaf litter from Acer campestre L. and Robinia pseudoacacia L., Table 6). This indicates that in the case of chemical load on the habitat, the actual food supply will not be a direct source, which enhances the accumulation of zinc content in the studied representatives of Diplopoda and their faecal pellets.

The environmental conditions have a direct impact on leaf litter consumption by saprophages, and litter decomposition. The study region is characterized by a difficult ecological state (pollution with heavy metals and other negative processes for ecosystems) and increased aridization. This leads to changes in the intensity of decomposition of leaf litter caused by soil saprophages, and in some cases inhibits their activity in decomposition. Consequently, the provision of such ecosystem services as increasing soil fertility and protecting the ecosystem from erosion will not be carried out by soil saprophages at the appropriate level. On the contrary, creating such conditions that prevent aridization (for example, protective forest belts, preservation of forest ecosystems), implementing control of pollution with heavy metals and reduction of their emissions in the study region are the processes that, in the conditions of poor watering in the steppe, would allow animals - ecosystem engineers - to perform their ecological functions, in this way increasing soil fertility.

The species composition, abundance and spatial distribution of soil invertebrates are informative indicators, which reflect the ecological state of soils, intensity of development of soil horizons as well as intensity of processes occurring in them (Andrusevich et al., 2018).

\section{Conclusions}

Modeling the consumption of litter of deciduous trees by such representatives of saprophages as woodlice $A$. vulgare showed that the conditions of both overwatering and poor moistening determine the mass of plant foliage consumed by them. In general, with increasing aridity of the steppe climate, woodlice reduce trophic activity (by 1.8 times compared with consumption under adequate moistening), which would reduce the zoogenic participation in such functions as increasing fertility and protecting soils against erosion. It is statistically proven that in the presence of chemical load on the environment of $R$. kessleri, the zinc contents in their 
bodies is due to the load, and at the same time, does not depend on the type of plant foliage consumed. In the control, the zinc content was 174.4 $\mathrm{mg} / \mathrm{kg}$, while in the conditions of the load $(0.15 \mathrm{mg} / \mathrm{L})$, this figure was almost three times higher $(512.14 \mathrm{mg} / \mathrm{kg})$ than under the highest chemical load of zinc solution. Due to the climate changes in the study region in the direction of aridity, it is possible to predict a decrease in the consumption of leaf litter by woodlice, which will negatively affect such forms of supporting ecosystem services as soil formation and nutrient cycling, carried out in forest ecosystem. The study of leaf litter destruction by woodlice and diplopods in artificial forest ecosystems with different light structures and under various chemical loads will make it possible to choose such options where these invertebrates will provide the forest ecosystem with their services at the best level.

\section{References}

Alexeyeva, A. A., Lykholat, Y. V., Khromykh, N. O., Kovalenko, I. M., \& Boroday, E. S. (2016). The impact of pollutants on the antioxidant protection of species of the genus Tilia at different developmental stages. Visnyk of Dnipropetrovsk University, Biology, Ecology, 24(1), 188-192.

Andrusevich, K. V., Nazarenko, M. M., Lykholat, T. Y., \& Grygoryuk, I. P. (2018). Effect of traditional agriculture technology on communities of soil invertebrates. Ukrainian Journal of Ecology, 8(1), 33-40.

Bibic, A., Drobne, D., Strus, J., \& Byrne, A. (1997). Assimilation of zinc by Porcellio scaber (Isopoda, Crustacea) expozed to zinc. Bulletin of Environmental Contamination and Toxicology, 58(5), 814-821.

Brigic, A., Bujan, J., Bedek, J., Antonovic, I., Sedlar, Z., Sostaric, R., \& Kepcija, R. M. (2019). Spatio-temporal changes of terrestrial isopod assemblages (Isopoda: Oniscidea) in a fen undergoing succession. Pedobiologia, 72, 16-22.

Brygadyrenko, V. V. (2014). Influence of soil moisture on litter invertebrate community structure of pine forests of the steppe zone of Ukraine. Folia Oecologica, 41(1), 8-16.

Brygadyrenko, V. V. (2015). Community structure of litter invertebrates of forest belt ecosystems in the Ukrainian steppe zone. International Journal of Environmental Research, 9(4), 1183-1192.

Brygadyrenko, V., \& Ivanyshyn, V. (2015). Changes in the body mass of Megaphyllum kievense (Diplopoda, Julidae) and the granulometric composition of leaf litter subject to different concentrations of copper. Journal of Forest Science, 61(9), 369-376.

Didur, O., Kulbachko, Y., \& Gasso, V. Y. (2017). Accumulation of microelements by different invertebrate trophic groups on wasted lands. Ukrainian Journal of Ecology, 7(4), 30-34.

Didur, O., Kulbachko, Y., \& Maltsev, Y. (2018). Impact of tropho-metabolic activity of earthworms (Lumbricidae) on distribution of soil algae within Acer platanoides L. plantation in recultivated territories of Western Donbass (Ukraine). Ukrainian Journal of Ecology, 8(2), 18-23.

Ghemari, C., Waterlot, C., Ayari, A., Douay, F., \& Nasri-Ammar, K. (2019). Effects of heavy metals artificial contamination on Porcellio laevis (Latreille, 1804) (Crustacea: Isopoda: Oniscidea). Bulletin of Environmental Contamination and Toxicology, 103(3), 416-420.

Gongalsky, K. B., Savin, F. A., Pokarzhevskii, A. D., \& Filimonova, Z. V. (2005). Spatial distribution of isopods in an oak-beech forest. European Joumal of Soil Biology, 41, 117-122.

Gritsan, Y. I. (2000). Ekolohichni osnovy peretvoryuyuchoho vplyvu lisovoyi roslynnosti na stepove seredovyshche [Ecological bases of transforming influence of forest vegetation on steppe environment], DNU, Dnipro (in Ukrainian).

Hassall, M., \& Dangerfield, J. M. (1990). Density-dependent processes in the population dynamics of Armadillidium vulgare (Isopoda: Oniscidae). Journal of Animal Ecology, 59(3), 941-958.

Hassall, M., Tuck, J. M., Smith, D. W., Gilroy, J. J., \& Addison, R. K. (2002). Effects of spatial heterogeneity on feeding behavior of Porcellio scaber (Isopoda: Oniscidea). European Journal of Soil Biology, 38, 53-57.

Horvath, G., Garamszegi, L. Z., Bereczki, J., Urszan, T. J., Balazs, G., \& Herczeg, G. (2019). Roll with the fear: Environment and state dependence of pill bug ( $\mathrm{Ar}$ madillidium vulgare) personalities. Science of Nature, 106(3-4), 7 .

Jaksova, P., L'uptacik, P., Miklisova, D., Horvathova, F., \& Hlavata, H. (2020). Oribatida (Acari) communities in arable soils formed under waterlogged conditions: The influence of a soil moisture gradient. Biologia, 75(2), 243-257.

Johnson, S. N., Lopaticki, G., Aslam, T. J., Barnett, K. A., Frew, S. E., Hartley, I., Hiltpold, U. N., Nielsen, J., \& Ryalls, M. W. (2018). Dryland management regimes alter forest habitats and understory arthropod communities. Annals of Applied Biology, 172(3), 282-294.

Jones, C. G., Lawton, J. H., \& Shachak, M. (1997). Positive and negative effects of organisms as physical ecosystem engineers. Ecology, 78(7), 1946-1957.

Klymenko, G., Kovalenko, I., Lykholat, Y., Khromykh, N., Didur, O., \& Alekseeva, A. (2017). Intehralna otsinka stanu populiatsii ridkisnykh vydiv roslyn [The integral assessment of the rare plant populations]. Ukrainian Journal of Ecology, 7(2), 201-209 (in Ukrainian).

Kovacs, B., Tinya, F., \& Odor, P. (2017). Stand structural drivers of microclimate in mature temperate mixed forests. Agricultural and Forest Meteorology, 234, 11-21.

Koval, V. V., Natalochka, V. O., Tkachenko, S. K., \& Minenko, O. V. (2012). Dynamika zabrudnennya vod sil's'kohospodars' $k$ oho pryznachennya solyamy vazhkykh metaliv v umovakh Poltavshchyny [Dynamics of agricultural water pollution by heavy metal salts in Poltava region]. Bulletin of the Poltava State Agrarian Academy, 1, 40-44 (in Russian).

Leclercq-Dransart, J., Pernin, C., Demuynck, S., Grumiaux, F., Lemière, S., \& Leprêtre, A. (2019). Isopod physiological and behavioral responses to drier conditions: An experiment with four species in the context of global warming. European Journal of Soil Biology, 90, 22-30.

Manu, M., Honciuc, V., Neagoe, A., Bancila, R. I., Iordache, V., \& Onete, M. (2019). Soil mite communities (Acari: Mesostigmata, Oribatida) as bioindicators for environmental conditions from polluted soils. Scientific Reports, 9, 20250.

Marina, I. C., Oprea, E., Gean, E., Chifiriuc, I., Carmen, M., \& Lazăr, V. (2014) Antimicrobial and antioxidant activity of the vegetative and reproductive organs of Robinia psendoacacia. Journal of the Serbian Chemical Society, 79(11), 1363-1378.

Meentemeyer, V. (1978). Macroclimate and lignin control of litter decomposition dynamics. Ecology, 59, 465-472.

Nae, I., \& Bancila, R. I. (2017). Mesovoid shallow substratum as a biodiversity hotspot for conservation priorities: analysis of oribatid mite (Acari: Oribatida) fauna. Acarologia, 57(4), 855-868.

Pakhomov, A. E., Kulbachko, Y. L., Didur, O. A., \& Loza, I. (2009). Mining dump rehabilitation: The potential role of bigeminate-legged millipeds (Diplopoda) and artificial mixed-soil habitats. In: Apostol, I., Barry, D. L., Coldewey, W. G., \& Reimern, D. W. G. (Ed.). Optimisation of disaster forecasting and prevention measures in the context of human and social dynamics. Vol. 52. IOS Press, Amsterdam-Berlin-Tokyo-Washington. Pp. 163-171.

Paoletti, M. G., \& Hassall, M. (1999). Woodlice (Isopoda: Oniscidea): Their potential for assessing sustainability and use as bioindicators. Agriculture, Ecosystems \& Environment, 74, 157-165.

Papp, D., Simon, E., Nagy, L., Mizser, S., \& Tóthmérész, B. (2019). The effect of urbanization on trace element concentration and symmetry of woodlice (Armadillidium vulgare Latreille, 1804). Biological Trace Element Research, 189(1), 251-258.

Pey, B., Tran, C., Cruz, P., Hedde, M., Jouany, C., Laplanche, C., Nahmani, J., Chauvet, E., \& Lecerf, A. (2018). Nutritive value and physical and chemical deterrents of forage grass litter explain feeding performances of two soil macrodetritivores. Applied Soil Ecology, 133, 81-88.

Pokhylenko, A., Lykholat, O., Didur, O., Kulbachko, Y., \& Lykholat, T. (2019). Morphological variability of Rossiulus kessleri (Diplopoda, Julida) from different biotopes within steppe zone of Ukraine. Ukrainian Journal of Ecology, 9(1), $176-182$.

Quadros, A. F., \& Araujo, P. B. (2008). An assemblage of terrestrial isopods (Crustacea) in Southern Brazil and its contribution to leaf litter processing. Revista Brasileira de Zoologia, 25(1), 58-66

Roy, S. N., \& Joy, V. C. (2009). Dietary effects of non-nutrients in the leaf litter of forest trees on assimilation, growth and tissue composition of the detritivorous soil arthropod Anoplodesmus saussurei (Humb.) (Polydesmida: Diplopoda). Applied Soil Ecology, 43, 53-60

Rushton, S. P., \& Hassall, M. (1987). Effects of food quality on isopod population dynamics. Functional Ecology, 1(4), 359-367.

Schmalfuss, H. (2000). Distributional patterns in the Greek species of the terrestrial isopod genus Armadillidium Brandt, 1833. Belgian Journal of Zoology, 130(Suppl. 1), 75-80.

Schmalfuss, H. (2003). World catalog of terrestrial isopods (Isopoda: Oniscidea) Stuttgarter Beitrage zur Naturkunde. Serie A. Vol. 654

Semenov, D. O., Fatjejev, A. I., Smirnova, K. B., Shemet, A. M., Lykova, O. A. Tyutyunnyk, N. V., \& Pogromska, I. A. (2019). Geochemical and anthropogenic factors of variability of heavy metals content in the soils and crops of Ukraine at the example of copper. Environmental Monitoring and Assessment, 8, 527.

Semenyuk, I. I., \& Tiunov, A. V. (2011). Isotopic signature $\left({ }^{15} \mathrm{~N} /{ }^{14} \mathrm{~N}\right.$ and $\left.{ }^{13} \mathrm{C} /{ }^{12} \mathrm{C}\right)$ confirms similarity of trophic niches of millipedes (Myriapoda, Diplopoda) in a temperate deciduous forest. Biological Bulletin, 38, 283-291.

Sfenthourakis, S., \& Hornung, E. (2018). Isopod distribution and climate change. Zookeys, 801, 25-61.

Shulman, M. V., Pakhomov, O. Y., \& Brygadyrenko, V. V. (2017). Effect of lead and cadmium ions upon the pupariation and morphological changes in Calliphora vicina (Diptera, Calliphoridae). Folia Oecologica, 44(1), 28-37.

Solomou, A. D., Sfougaris, A. I., \& Sfenthourakis, S. (2019). Terrestrial isopods as bioindicators for environmental monitoring in olive groves and natural ecosystems. Journal of Natural History, 53, 1721-1735. 
Spaldonova, A., \& Frouz, J. (2019). Decomposition of forest litter and feces of $\mathrm{Ar}$ madillidium vulgare (Isopoda: Oniscidea) produced from the same litter affected by temperature and litter quality. Forests, 10(11), 939.

Straalen, N. M., Butovsky, R. O., Pokarzhevskii, A. D., \& Zaitsev, A. S. (2001) Metal concentration in soil and invertebrates in the vicinity of a metallurgical factory near Tula (Russia). Pedobiologia, 45(5), 451-466.

Striganova, B. R. (1980). Pitanie pochvennyh saprofagov [The feeding of soil saprophages]. Nauka, Moscow (in Russian).

Svyrydchenko, A. O., \& Brygadyrenko, V. V. (2014). Trophic preferences of Rossiulus kessleri (Diplopoda, Julidae) for the litter of various tree species. Folia Oecologica, 41, 202-212.

Tateno, R., Tokuchi, N., Yamanaka, N., Du, S., Otsuki, K., Shimamura, T., Xue, Z. D., Wang, S. Q., \& Hou, Q. C. (2007). Comparison of litterfall production and leaf litter decomposition between an exotic black locust plantation and an indigenous oak forest near Yan'an on the Loess Plateau, China. Forest Ecology and Management, 241, 84-90.

van Gestel, C. A. M., Loureiro, S., \& Zidar, P. (2018). Terrestrial isopods as model organisms in soil ecotoxicology: A review. Zookeys, 801, 127-162.

Vasconcelos, H. L., \& Laurance, W. F. (2005). Influence of habitat, litter type, and soil invertebrates on leaf-litter decomposition in a fragmented Amazonian landscape. Oecologia, 144, 456-462.

Yang, X., Shao, M. A., \& Li, T. C. (2020). Effects of terrestrial isopods on soil nutrients during litter decomposition. Geoderma, 376, 114546.

Zhang, G. J., Li, Y., Xu, Z. H., Jiang, J. Z., Han, F. B., \& Li, J. H. (2012). The chemical composition and ruminal degradation of the protein and fibre of tetraploid Robinia pseudoacacia harvested at different growth stages. Journal of Animal and Feed Sciences, 21(1), 177-187. 